\title{
Digenean parasites of Cariama cristata (Aves, Gruiformes) from Formosa Province, Argentina, with the description of a new species of the genus Strigea
}

\author{
Lía Inés Lunaschi* and Fabiana Beatriz Drago \\ Laboratorio de Helmintología, División Zoología Invertebrados, Museo de La Plata, Paseo del Bosque S/No 1900 La Plata, \\ Buenos Aires, Argentina
}

\begin{abstract}
A new strigeid digenean, Strigea inflecta sp. nov., is described from the small intestine of the Red-legged Seriema, Cariama cristata (L.) (Gruiformes, Cariamidae) from Formosa Province, Argentina. This species is characterized by having a body plump, a cup-shaped forebody with a large opening, a sacciform hindbody, without a neck region and strongly curved dorsally, a poorly delimited copulatory bursa, wider than longer, a shallow and asymmetrical genital atrium, and a genital cone well delimited from body parenchyma, strongly muscular, inclined towards the surface ventral of the body. Another digenean species collected from Red-legged Seriema, Brachylaima yupanquii Freitas, Kohn et Ibáñez, 1967 (Brachylaimidae) is described with the addition of new morphological characters and morphometrical data. This species is reported for the first time in Argentina and C. cristata represents a new host record.
\end{abstract}

\section{Keywords}

Strigeidae, Strigea inflecta sp. nov., Brachylaimidae, Brachylaima yupanquii, Cariamidae, Argentina

\section{Introduction}

The Red-legged Seriema, Cariama cristata (L.) (Gruiformes, Cariamidae), is among the largest birds endemic to the Neotropical Region, exclusively inhabiting a zone of South America between E Brazil, E Bolivia and Paraguay to Uruguay and central Argentina. It feeds mainly on arthropods, insect larvae, lizards, snakes, small vertebrates, grain and wild fruit (Gonzaga 1996). The helminth fauna of $C$. cristata has been poorly studied, so far seven species of helminths have been recorded parasitizing this species: Ascaridia pterophora (Creplin, 1845) (Nematoda) from Perú and Brazil; Athesmia heterolecithodes (Braun, 1899); Strigea vaginata (Brandes, 1888) (Digenea); Oxyspirura brevipenis (Molin, 1860), Cramispirura altensis (Rodrigues, 1962) (Nematoda); Oligacanthorhynchus taenioides (Diesing, 1851) (Acanthocephala) and Idiogenes horridus Fuhrmann, 1908 (Cestoda) from Brazil (Ransom 1904, 1911; Schultz 1939; Freitas and Ibáñez 1965; Travassos et al. 1969, Cristofaro and Feijo 1976).

The purpose of this paper is to increase the knowledge of the diversity of digenean parasites of the Red-legged Seriema, C. cristata, from Formosa Province, Argentina.

\section{Materials and methods}

The digeneans were collected from one specimen of C. cristata from La Marcela farm (26 $\left.17^{\prime} 35^{\prime \prime} \mathrm{S} ; 59^{\circ} 06^{\prime} 67^{\prime \prime} \mathrm{W}\right)$, Pirané, Formosa Province, Argentina, on September 2009. The bird was dissected in the field and the viscera preserved in $10 \%$ formalin and transported to the laboratory for examination. The digenean specimens were removed, stored in $70 \%$ ethanol, stained with a 1:6 dilution in $96 \%$ ethanol of hydrochloric carmine, dehydrated and mounted between two microscope cover glasses in Canada balsam. Measurements are given in micrometers $(\mu \mathrm{m})$ unless otherwise stated, as the range followed by mean in parentheses. Drawings were made with the aid of a drawing tube. In the description of specimens of Brachylaima Dujardin, 1843, the forebody is defined as the distance from the anterior end of body to the anterior border of the ventral sucker, and the hindbody from the posterior border of the ventral sucker to the posterior end. In the description of specimens of Strigea Abildgaard, 1790 the forebody and hindbody are defined according to Niewiadomska (2002). The abbreviations of relative proportions (ratios) are as follows: B/E: body length/egg length; BL/BW: body length/body 
width; Gc/E: genital cone length/egg length; Hi/E: hindbody length/egg length; Hi/Fo: hindbody length/forebody length; $\mathrm{Hi} / \mathrm{Gc}$ : hindbody length/genital cone length; Os/Ph: ratio oral sucker length/pharynx length; Ph/Os: pharynx length/oral sucker length; T/O: ratio testes length/ovary length; Vs/Os: sucker width ratio.

\section{Results}

\section{Strigeidae Railliet, 1919}

Strigea inflecta sp. nov. (Figs 1 and 2; Tables I and II)

Description (based on 6 specimens). Body plump, 1.605$1.982 \mathrm{~mm}(1.795 \mathrm{~mm})$ in total length. Tegument smooth. Forebody cup-shaped, with a large opening, 0.561-0.754 $\times$ $0.783-1.006 \mathrm{~mm}(652 \times 899)$. Hindbody sacciform, strongly curved dorsally, without neck, about 2 times longer than forebody, $0.967-1.257 \times 0.532-0.841 \mathrm{~mm}(1.143 \times 0.675$ $\mathrm{mm})$. Hindbody length to forebody length ratio $1: 1.5-2.1$ (1:1.8). Oral sucker terminal, well developed, 183-241 $\times$ 126-155 $(212 \times 143)$. Ventral sucker well developed, always larger than oral sucker, 179-290 × 174-256 $(244 \times 223)$. Suckers width ratio 1:1.4-1.7 (1.5). Pseudosuckers conspicuous, about midway between suckers. Holdfast organ lobes occasionally projected from opening; proteolytic gland at base of forebody $72-121 \times 121-174$. Prepharynx absent; pharynx larger than oral sucker, 140-169 × 109-126 (158 $\times$ 119); oesophagus and intestinal caeca not discernible. Pharynx length to oral sucker length ratio 1:0.7-0.8. Testes in tandem, of variable appearance, cuneiform, or moderately lobed, occupying middle third of hindbody; anterior testis $135-232 \times 401-483(171 \times 440)$; posterior testis $150-193 \times$ $338-483(171 \times 425)$. Seminal vesicle long and folded on itself, posterior to posterior testis. Ovary ovoid, dorsal, 111$237 \times 155-222(169 \times 190)$ at $242-290(274)$ from junction of fore- and hindbody. Laurer's canal short, opening dorsally between ovary and anterior testis. Vitelline follicles similar in size in both parts of body; in forebody concentrated in base of holdfast organ and wall of body; slightly exceeding level of ventral sucker in dorsolateral region, and few follicles penetrate base of forebody in ventral region; in hindbody occupying almost whole width in preovarian region and extending ventrally to testes and terminating in the region of copulatory bursa. Mehlis' gland and vitelline reservoir in intertesticular region. Uterus ventral containing large eggs, $86-111 \times 50-58(104 \times 55)$. Body length to egg length ratio 1:16-19 (1:17). Copulatory bursa poorly delimited, wider than longer, 314-435 × 483-652; genital atrium slightly, asymmetrical, 232-290 in depth; pore terminal, genital cone well delimited from body parenchyma, strongly muscular, inclined towards ventral surface of body, and opens close to ventral wall of copulatory bursa, 372-435 × 203-319; ejaculatory duct and uterus join at base of genital cone forming long and folded hermaphroditic duct. Muscular ring (Ring- napf) absent. Ratio of hindbody length to genital cone length 1:2.4-3.1. Ratio of genital cone length to egg length $1: 3.5$ 4.8 (1:4.1). Excretory vesicle and pore, not observed.

\section{Taxonomic summary}

Type host: Cariama cristata (L.) (Gruiformes, Cariamidae). Site of infection: small intestine.

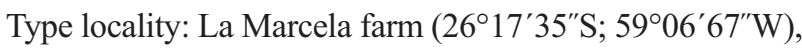
Pirané, Formosa Province, Argentina.

Type material: Holotype MLP 6445; paratypes, 5 specimens, MLP 6446.

Intensity of infection: 10 .

Etymology: The specific name is derived from the body shape.

Remarks: The genus Strigea is represented in the Neotropical region by 12 species of which only 4 have the hindbody moderately to strongly curved dorsally: Strigea elliptica (Brandes, 1888) Szidat, 1928, described parasitizing Bubo virginianus nacurutu (Vieillot) (Strigidae) and Buteogallus meridionalis (Latham) (Accipitridae) from Brazil and Argentina, respectively, Strigea caluri Dubois, 1962 described parasitizing Pharomachrus mocinno De la Llave (Trogonidae) from Central America, Strigea sphaerocephala Westrumb, 1823 in Icteridae, Cotingidae and Anatidae from Brazil and Venezuela and S. vaginata in Cathartidae, Falconidae, Accipitridae, Cariamidae, Threskiornithidae and Anatidae from Colombia, Venezuela, Brazil and Cuba (Lunaschi and Drago 2009). Strigea elliptica, differs from the specimens described here by having a calyciform forebody with a small aperture, a larger posterior testis, a smaller ovary and genital cone and by possessing a well developed muscular ring (Ringnapf). Strigea sphaerocephala differs by possessing the forebody of greater diameter with large oblique opening, a slightly arched hindbody, with a non-delimited copulatory bursa and rounded testes. Strigea caluri differs in having the testes deeply lobed, a copulatory bursa with a membranous fold originating from the muscular ring (Ringnapf) surrounding the genital cone. Finally, $S$. vaginata differs in having the vitelline glands in the forebody most densely concentrated in the lips of the holdfast organ, and by the enormous genital cone, reaching up to half the length of the hindbody (see Table I). Three other taxa of the genus are similar to $S$. inflecta sp. nov., namely Strigea sphaerula macrosicya Dubois et Rauch, 1950, Strigea sphaerula sphaerula (Rudolphi, 1803) Mathias, 1925 and Strigea subglandulosa Dubois et Beverley-Burton, 1971, the first two taxa having been reported in the Holarctic Region as parasites of passeriform and coraciiform birds, and the third species in falconiform birds from the Ethiopian Region. These resemble the new species principally in their body plump, the forebody being wider than long, with a large opening through which holdfast organ lobes can protrude, a sacciform or reniform hindbody and by possessing a poorly 


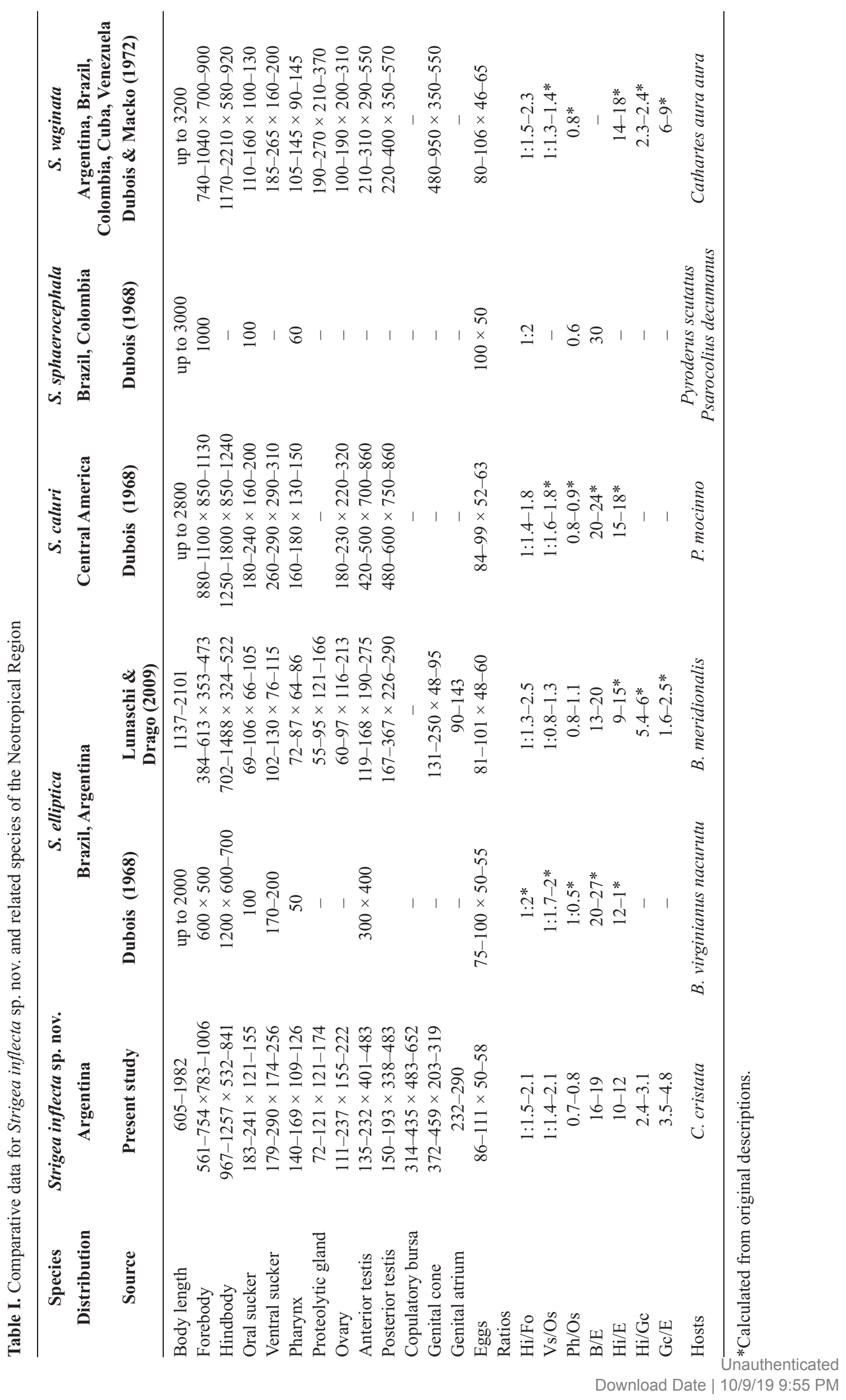


delimited copulatory bursa and lacking of muscular ring or "Ringnapf". Strigea sphaerula macrosicya, described parasitizing Corvus corax principalis Ridgway (Passeriformes) from Alaska, differs from the new species by having larger suckers and pharynx, and a smaller genital cone. Strigea sphaerula sphaerula, reported in Corvus corone L., Corvus frugilegus L., Garrulus glandarius (L.), Lanius collurio L. (Passeriformes), Coracias garrulus L. (Coraciiformes) from Eurasia, can be distinguished by having larger testes and eggs, and by having a smaller genital cone. Finally, S. subglandulosa, described in Circus ranivorus (Daudin) (Falconiformes) from Zambia, differs from Strigea inflecta sp. nov. in most metrical characters, i.e. the smaller size of the body, the suckers, pharynx, genital cone, and the depth of genital atrium, a longer ovary and wider testes (see Table II). Moreover, this species differs for possessing muscular ring or "Ringnapf", and by the distribution of vitelline follicles in the forebody.
Brachylaimidae Joyeux et Foley, 1930

Brachylaima yupanquii Freitas, Kohn et Ibáñez, 1967 (Figs 3-5, Table III)

Description (based on 6 mature specimens): Body elongate, linguiform, $1.6-3.9 \mathrm{~mm}(2.8 \mathrm{~mm})$ long by $0.586-1.029 \mathrm{~mm}$ $(0.788 \mathrm{~mm})$ wide. Ratio length/width of body $1: 3.3-4(1: 3.7)$ Forebody 483-803 (670) long, 19-31\% of body length; hindbody longer than forebody, $1.5-2.9 \mathrm{~mm}(2.04 \mathrm{~mm})$ long. Hindbody length to forebody length ratio 1:2.5-3.9 (1:3). Tegument spined around anterior end. Oral sucker subterminal, $227-338$ long by $217-300$ wide $(278 \times 267)$. Ventral sucker well developed, larger than oral sucker, located in first quarter of body, 227-362 long by 241-386 wide $(305 \times 317)$. Sucker-width ratio 1:1.1-1.3 (1:1.2). Inter-sucker distance 101-532 (344). Prepharynx absent; pharynx muscular, well developed, 119-193 long by 145-232 wide $(172 \times 193)$; oesophagus not discernible; intestinal caeca narrow and sinuous

Table II. Comparative data for Strigea inflecta sp. nov. and related species of the Neotropical Region

\begin{tabular}{|c|c|c|c|c|}
\hline Species & Strigea inflecta sp. nov. & S. sphaerula macrosicya & S. sphaerula sphaerula & S. subglandulosa \\
\hline Distribution & Argentina & Alaska & Eurasia & Zambia \\
\hline Source & Present study & Dubois (1968) & Dubois (1968) & $\begin{array}{c}\text { Dubois \& } \\
\text { Beverley-Burton (1971) } \\
\end{array}$ \\
\hline Body length & $1605-1982$ & $1950-2250$ & up to 3000 & $1040-1340$ \\
\hline Forebody & $561-754 \times 783-1006$ & $660-750 \times 1050$ & $420-1080 \times 630-1350$ & $400-470 \times 450-580$ \\
\hline Hindbody & $967-1257 \times 532-841$ & $1500 \times 780-1020$ & $660-1710 \times 520-1050$ & $640-960 \times 360-560$ \\
\hline Ventral sucker & $179-290 \times 174-256$ & $350-360 \times 290-315$ & $220-315 \times 160-300$ & $135-185 \times 90-160$ \\
\hline Pharynx & $140-169 \times 109-126$ & $180-215 \times 180-190$ & $100-165 \times 90-165$ & $60-84 \times 68-86$ \\
\hline Proteolytic gland & $72-121 \times 121-174$ & - & - & $100-155 \times 180-245$ \\
\hline Ovary & $111-237 \times 155-222$ & $160 \times 230$ & $180-200 \times 150-260$ & $60-120 \times 125-220$ \\
\hline Anterior testis & $135-232 \times 401-483$ & $200-390$ & $310-500 \times 210-450$ & $100-200 \times 210-330$ \\
\hline Genital atrium & $232-290$ & $210-350$ & $150-180$ & $140-220$ \\
\hline Eggs & $86-111 \times 50-58$ & $100-108 \times 60-63$ & $100-123 \times 60-77$ & $85-94 \times 52-63$ \\
\hline \multicolumn{5}{|l|}{ Ratios } \\
\hline $\mathrm{Hi} / \mathrm{Fo}$ & $1.5-2.1$ & $1.8-1.9^{*}$ & $1.1-2.7^{*}$ & $1.47-2.25$ \\
\hline $\mathrm{Vs} / \mathrm{Os}$ & $1.4-2.1$ & $1.2^{*}$ & $1.5-1.6^{*}$ & $1.1-1.5^{*}$ \\
\hline $\mathrm{Ph} / \mathrm{Os}$ & $0.7-0.8$ & 0.7 & $0.6-0.9$ & $0.6^{*}$ \\
\hline $\mathrm{B} / \mathrm{E}$ & $16-19$ & $20-21 *$ & $24-30 *$ & $12-14 *$ \\
\hline $\mathrm{Hi} / \mathrm{E}$ & $10-12$ & $14-15^{*}$ & $7-14^{*}$ & $7-10^{*}$ \\
\hline $\mathrm{Hi} / \mathrm{Gc}$ & $2.4-3.1$ & $5-5.3^{*}$ & $5.5-7.3^{*}$ & $5.3-6^{*}$ \\
\hline
\end{tabular}

*Calculated from original descriptions. 

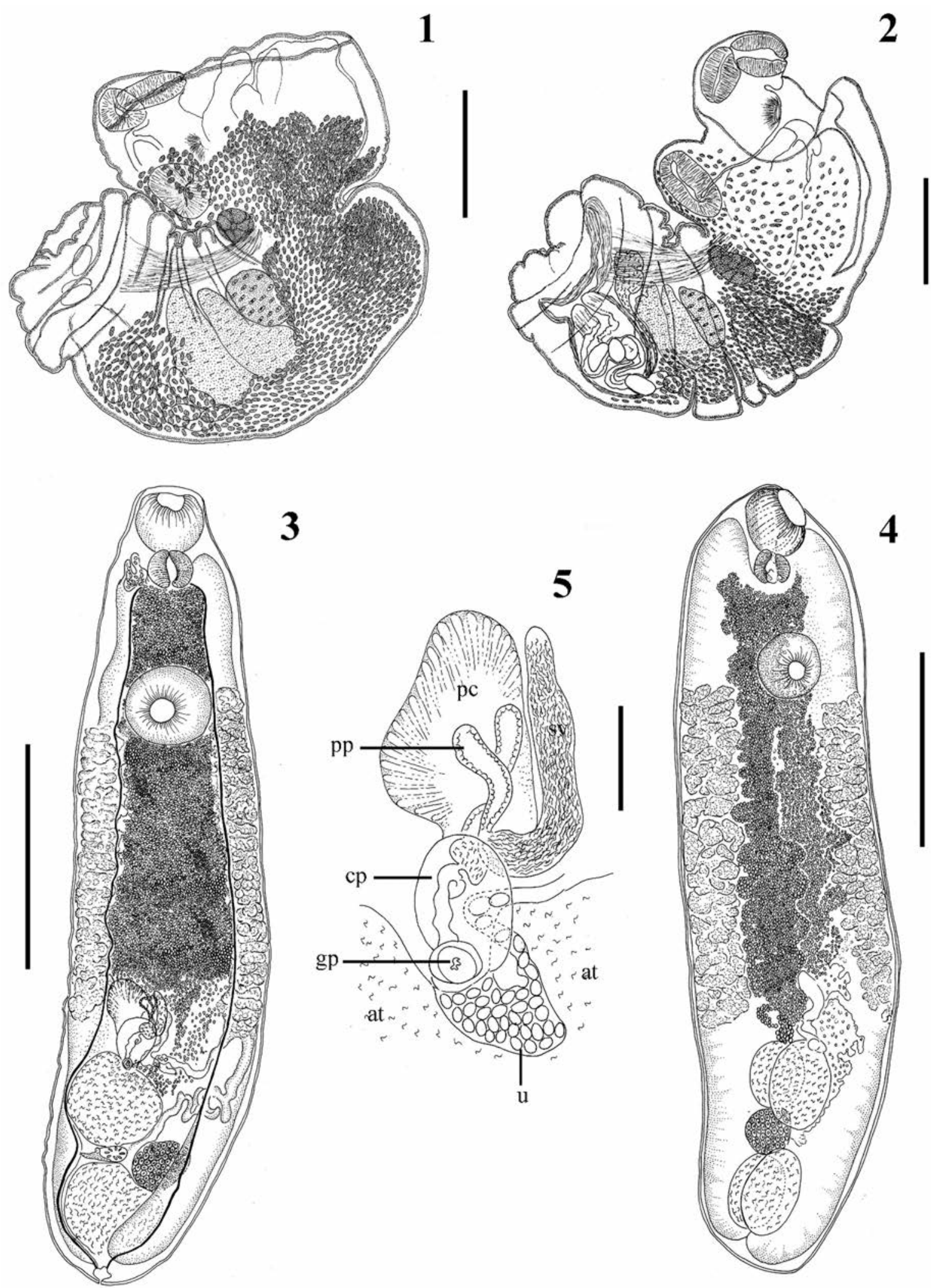

Digeneans from Cariama cristata. Figs 1-2. Strigea inflecta sp. nov. 1. Holotype, entire worm, lateral view. Scale bar $=200 \mu \mathrm{m} . \mathbf{2}$. Paratype, entire worm, lateral view. Scale bar $=300 \mu \mathrm{m}$. Figs 3-5. Brachylaima yupanquii. 3 and 4. Entire worm, ventral view. 4. Specimen showing the bilobed appearance of testes. Scale bar $=1 \mathrm{~mm}$. 5. Enlarged ventral view of terminal genitalia. Scale bar $=100 \mu \mathrm{m}$. Abbreviations: at - anterior testis, $\mathrm{cp}$ - cirrus pouch, $\mathrm{gp}$ - genital pore, $\mathrm{pc}$ - prostatic cells, $\mathrm{pp}$ - pars prostatic, $\mathrm{sv}$ - seminal vesicle, $\mathrm{u}$ - uterus 


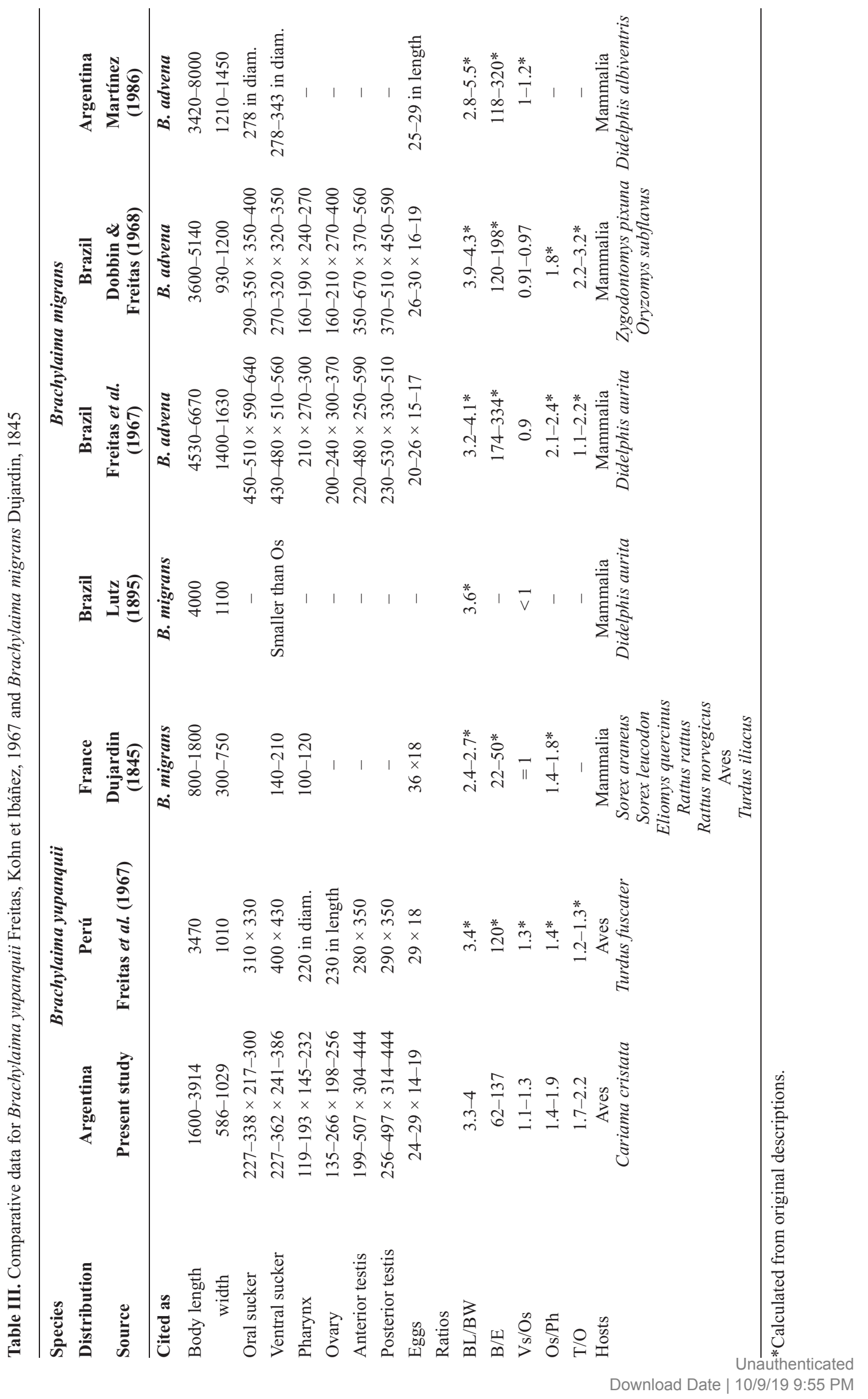


or conspicuously widened and straight, extending to near posterior body end. Ratio oral sucker length to pharynx length 1:1.4-1.9 (1:1.6). Gonads in tandem, located in posterior quarter of body. Genital pore ventral, pretesticular, near anterior margin of anterior testis, surrounded by gland cells free in parenchyma. Cirrus sac 76-118 long by 45-74 wide $(94 \times 56)$, containing only unarmed cirrus; seminal vesicle elongate, tubular; pars prostatica long surrounded by numerous prostatic cells. Testes round to oval, (in one specimen with bilobed appearance due to pressure caused by caeca), up to 2 times larger than ovary; anterior testis $299-507$ long by $304-444$ wide $(406 \times 388)$; posterior testis $256-497$ long by $314-444$ wide $(391 \times 374)$. Ovary spherical to cuneiform, intertesticular, 135-266 long by $198-256$ wide $(214 \times 227)$. Ratio testes length to ovary length 1.7-2.2:1 (1.9:1). Mehlis gland lateral to ovary and intertesticular; Laurer's canal short. Uterus intercaecal, entirely preovarian, extends anteriorly, reaching pharynx. Metraterm short, muscular, 95-120 long (101). Vitelline bands composed of caecal and extracaecal follicles, extend from ventral sucker to pretesticular region. Eggs numerous, small, light brown, 24-29 long by 14-19 wide (27 $\times$ 17). Ratio of body length to egg length 90-137:1 (120:1). Excretory vesicle short, Y-shaped, posterior to extremities of caeca, with two long main excretory canals. Excretory pore terminal.

\section{Taxonomic summary}

Host: Cariama cristata (L.) (Gruiformes, Cariamidae).

Site of infection: small intestine.

Locality: La Marcela farm $\left(26^{\circ} 17^{\prime} 35^{\prime \prime} \mathrm{S} ; 59^{\circ} 06^{\prime} 67^{\prime \prime} \mathrm{W}\right)$, Pi-

rané, Formosa Province, Argentina.

Intensity of infection: 18.

Material deposited: MLP 6444.

Remarks: The family Brachylaimidae includes seven genera, principally parasites of the alimentary tract of birds and mammals, and with a life cycle that includes only terrestrial molluscs as intermediate hosts. The type-genus, Brachylaima has been reported in South America as a parasite of passeriform, galliform and columbiform birds naturally infected from Brazil, Venezuela and Perú, and dasipodid, didelphid, murid and cricetid mammals from Brazil and Argentina. At present, five species of Brachylaima have been described as parasites of South American birds: B. yupanquii parasitizing Turdus fuscater d'Orbigny et Lafresnaye (Turdidae) from Perú; Brachylaima digiustii Nasir et Rodríguez, 1966 in columbids from Venezuela; Brachylaima mazzantii (Travassos, 1927) Freitas et Kohn, 1964 in columbids from Brazil; Brachylaima mordens (Braun, 1901) in rallids from Brazil and Brachylaima marsupium (Braun, 1901) Dollfus, 1935 parasitizing galliforms from Brazil (Braun 1901, 1902; Travassos 1927, 1928; Dollfus 1935; Nasir and Rodriguez 1966; Freitas et al. 1967; Travassos et al. 1969; Yamaguti 1971; Corrêa Gomes and Magalhães Pinto 1978; Adriano et al. 2001). Moreover, Heyne- man et al. (1960) described an indeterminate species parasitizing a species of passeriform bird from Venezuela. Of these species reported to date, the specimens here described principally differ from B. mordens in the distribution of the uterus which does not extend anteriorly beyond the level of the ventral sucker. The remaining species share with the specimens recovered from $C$. cristata the extension of the uterus which reaches into the inter-sucker region. Nevertheless, $B$. marsupium, B. digiustii and B. mazzantii differ from our specimens by the distribution of the vitelline follicles, which extend into the forebody whereas, $B$. yupanquii has a similar distribution of vitelline follicles. The specimens of $B$. yupanquii studied here, showed a wide variation in the body size, and the shape of the testes and ovary, which could be related with the degree of contraction of specimens. Given that B. yupanquii was originally described based on a single specimen, the present study has enabled us to augment the original description with new morphological characters and morphometrical data. The presence of B. yupanquii in C. cristata represents a new host record, the first record in gruiform birds and the first report in Argentinean birds.

On the other hand, we have observed that the type-species of the genus, Brachylaima migrans Dujardin, 1845 (syn. Brachylaima advena Dujardin, 1843 according to Butcher and Grove 2001) possesses morphological characters and morphometrical data similar to B. yupanquii (see Table III), however according Freitas et al.(1967), these species can be differentiated by the ratio ventral sucker/oral sucker, being higher than 1 in the last species.

Dujardin (1845) reported the presence of B. migrans parasitizing the following species of mammals and birds in France: Sorex araneus L., Sorex leucodon Herman (Rodentia: Soricidae), Eliomys quercinus L. (as Myoxus nitella) (Rodentia: Gliridae), Rattus rattus L. (as Mus rattus) and Rattus norvegicus Berkenhout (as Mus decumanus) (Rodentia: Muridae) and Turdus iliacus L. (as T. musicus) (Aves: Turdidae). In South America, this species was reported parasitizing several species of mammals infected naturally from Brazil (murids, cricetids, didelphids and dasypodids) and a species of didelphid marsupial from Argentina (Lutz 1895; Freitas et al. 1967; Dobbin and Freitas 1968; Travassos et al. 1969; Martínez 1986). In addition, Freitas et al. (1967) provide a long list of synonymous species of $B$. advena, extending its geographic distribution to North America, Africa, and Europa and, its list of natural hosts; and reported adult specimens obtained experimentally both in mammals and birds, such as Columba livia Gmelin, Numida meleagridis L. and Gallus gallus L. Given the above, B. migrans is a generalist species that parasitizes both mammals and birds.

The comparative analysis of the specimens here studied with those of B. yupanquii originally described in Perú, and B. migrans described in France, Brazil and Argentina (Table III), revealed that the specimens described by Martínez parasitizing Didelphis albiventris did not conform to the specific diagnosis of $B$. migrans by having a ventral sucker larger than 
oral sucker, and their correct identification corresponds to B. yupanquii. Therefore, this species as B. migrans can be found in the digestive tract of both birds and mammals.

Acknowledgments. Special thanks are due to Dr. Carlos Montoya for help and hospitality during our stay in La Marcela farm, Formosa Province. The authors, Lía Lunaschi and Fabiana Drago are members of the Comisión de Investigaciones Científicas de la Provincia de Buenos Aires (CIC) and Universidad Nacional de La Plata (UNLP), respectively. The present study was funded by CIC (Res. No. $1535 / 10)$.

\section{References}

Adriano E.A., Thyssen P.J., Cordeiro N.S. 2001. Brachylaima mazzantii (Trematoda): first record in Zenaida auriculata (Aves: Columbidae). Boletín Chileno de Parasitología, 56, 34-35. DOI: $10.4067 / \mathrm{S} 0365-94022001000100009$.

Braun M. 1901. Zur Revision der Trematoden der Vögel. II. Zentralblatt fur Bakteriologie, Abth. I, 29, 941-948.

Braun M. 1902. Fascioliden der Vögel. Zoologische Jahrbuecher, $16,1-162$.

Butcher A.R., Grove D.I. 2001. Description of the life-cycle stages of Brachylaima cribbi n. sp. (Digenea: Brachylaimidae) derived from eggs recovered from human faeces in Australia. Systematic Parasitology, 49, 211-221. DOI: 10.1023/A:101061 6920412

Corrêa Gomes D., Magalhães Pinto R. 1978. Contribuição ao conhecimento da fauna helmintológica da região amazõnica Trematodeos. Atas da Sociedade de Biologia do Rio de Janeiro, 19, 43-46.

Cristofaro R., Feijo L.M.F. 1976. Contribução ao estudo da fauna helmintologica do Estado Mato Grosso. Atas da Sociedade de Biologia do Rio de Janeiro, 18, 53-57.

Dobbin J.E., Freitas J.F.T. 1968. Ocorrência de Brachilaemus (Brachylaemus) advena Dujardin, 1943 em novos hospedeiros no nordeste brasileiro (Trematoda). Atas da Sociedade de Biologia do Rio de Janeiro, 11, 179-180.

Dollfus R. 1935. Sur quelques Brachylaemus de la faune française récoltés principalement a Richelieu (Indre et Loire). Annales des Parasitologie, 13, 52-79.

Dubois G. 1968. Synopsis des Strigeidae et des Diplostomatidae (Trematoda). Mémoires de la Société Neuchâteloise des Sciences Naturelles, 10, 1-258.

Dubois G., Macko J. 1972. Contribution a l'étude de Strigeata La Rue, 1926 (Trematoda: Strigeida) de Cuba. Annales de Parasitologie Humaine et Comparée, 47, 51-75.
Dubois G., Beverley-Burton M. 1971. Quelques Strigeata (Trematoda) d'oiseaux de Rhodesie et de Zambie. Bulletin de la Societé Neuchateloise des Ciences Naturelles, 94, 5-19.

Dujardin F. 1845. Histoire Naturelle des Helminthes ou vers intestinaux. Librairie Encyclopédique de Roret, París, 54 pp.

Freitas J.F.T., Ibáñez H.N. 1965. Fauna helmintológica do Perú. Nova espécie do gênero Ascaridia Dujardin, 1845 (Nematoda, Ascaridoidea). Memorias do Instituto Oswaldo Cruz, 63, 51-58.

Freitas J.F.T., Kohn A., Ibáñez H.N. 1967. Sôbre as espécies de Brachylaemus (Brachylaemus) Dujardin1843 (Trematoda). Memorias do Instituto Oswaldo Cruz, 65, 41-61.

Heyneman D., Brenes R.R., Díaz-Ungría C. 1960. Trematodos de Venezuela. II. Algunos trematodos de peces, reptiles y aves con descripción de una nueva especie del género Lubens. Memoria de la Sociedad de Ciencias Naturales La Salle, 20, $138-149$

Gonzaga L.P. 1996. Family Cariamidae. In: (Eds. J. del Hoyo, A. Elliot and J. Sargatal) Handbooks of the Birds of the World. Vol. 3. Hoatzin to Auks. Lynx Editions, Barcelona, 234-239.

Lunaschi L.I., Drago F.B. 2009. Species of Strigea (Digenea: Strigeidae), parasites of the savanna hawk Buteogallus meridionalis (Aves: Accipitridae) from Argentina, with the description of a new species. Folia Parasitologica, 56, 268-274.

Lutz A. 1895. Distoma ophisthotrias, um novo parasita do gambá. Revista do Museu Paulista, 1, 181-188.

Martínez F.A. 1986. Helmintofauna de los mamíferos silvestres. Trematodes. Veterinaria Argentina, 3, 544-551.

Nasir P., Rodriguez L.M. 1966. Brachylaima degiustii n. sp. from Columba livia in Venezuela. Proceedings of the Helminthological Society of Washington, 33, 170-172.

Niewiadomska K. 2002. Superfamily Diplostomoidea Poirier, 1886. In: (Eds. D.I. Gibson, A. Jones and R.A. Bray) Keys to the Trematoda. Vol. 1. CABI Publishing and The Natural History Museum, Wallingford, 159-166.

Ransom B.H. 1904. Manson's eye worm of chickens (Oxyspirura mansoni), with a general review of nematodes parasitic in the eyes of birds, and notes on the spiny-suckered tapeworms of chickens (Davainea echinobothrida [= Taenia botrioplites] and D. tetragona). Bulletin Bureau of Animal Industry, U.S. Department of Agriculture, 60, 1-73.

Ransom B.H. 1911. A new cestode from an African bustard. Proceedings of the United States National Museum, 40, 637-647.

Travassos L. 1927. Harmostomum de la Columba livia dom. Comptes Rendus Société de Biologie, Paris, 97, 844-846.

Travassos L. 1928. Fauna helminthologica de Matto Grosso. Memórias do Instituto Oswaldo Cruz, 21, 309-342.

Travassos L., Freitas J.F.T., Kohn A. 1969. Trematodeos do Brasil. Memórias do Instituto Oswaldo Cruz, 67, 1-886.

Yamaguti S. 1971. Synopsis of digenetic trematodes of vertebrates. Vol. 1. Keigaku Publishing Co., Tokyo, 1074 pp.

(Accepted January 12, 2012) 